\title{
Coordination Aspects of Dimethyldithiocarbamate Ligand towards the First Series Transition Metal Ions
}

\author{
MOHAMMAD TARIQUE \\ Department of Chemistry, B.I.T.S. Masuri,Ghaziabad (U.P.)-201302, India \\ mohammadtarique0@gmail.com
}

Received 10 May 2012 / Accepted 28 May 2012

\begin{abstract}
A series of chelates of first series transition metals with dimethyldithiocarbamate has been prepared. Physicochemical characterization of these chelates was done with the help of analytical data, molar conductance and FT-IR spectroscopy. All the colourless to colourful complexes were inert to atmospheric oxygen and moisture at room temperature. The analytical data indicated the composition $\mathrm{ML}_{2}$ for the chelates of $\mathrm{Mn}(\mathrm{II}), \mathrm{Co}(\mathrm{II}), \mathrm{Ni}(\mathrm{II}), \mathrm{Cu}(\mathrm{II})$ and $\mathrm{Zn}(\mathrm{II})$ and $\mathrm{M}^{\prime} \mathrm{L}_{3}$ for those of $\mathrm{Cr}(\mathrm{III})$ and $\mathrm{Fe}$ (III). These complexes were observed to be non-ionic in nature. The FT-IR spectral data revealed the symmetrical coordination by the ligand.
\end{abstract}

Keywords: Dithiocarbamates, Transition metal chelates, Coordination aspects, Metal ions

\section{Introduction}

Carbon disulphide, proved to be a versatile ligand ${ }^{1}$ greater tendency to react with various amines resulting the formation of an important class of compounds known as dithiocarbamates. Apart from their application in industry and agriculture, dithiocarbamates have achieved much more academic interest owing to their synthetic flexibility and dual nature of acting as monodentate as well as chelating ligand. The literature shows that the alkyl, haloalkyl, cycloalkyl, phenyl, benzyl, pyridyl, aniline, pyrolidine, indole, indoline and carbazole dithiocarbamates together with their derivatives have been synthesized and studied in detail ${ }^{2-8}$.

Due to the interest in the study of sulphur and nitrogen containing ligands ${ }^{9-19}$, this communication describes the preparation and characterization of complexes of first row transition metals with dimethyldithiocarbamate with the aim to observe the coordination behaviour of the dithiocarbamate moiety and some other physicochemical characteristics of these complexes.

\section{Experimental}

Dimethylamine, carbon disulphide, sodium hydroxide, salts of first row transition metals (all E. Merck) were used as received. Solvents (all BDH) were purified by standard methods ${ }^{20}$ before use. Elemental analyses of the complexes for carbon, hydrogen and nitrogen were 
performed by the regional sophisticated instrumentation centre (R.S.I.C.), central drug research institute (C.D.R.I.), Lucknow (U.P.), India. Sulphur was estimated gravimetrically by known procedure ${ }^{21}$.

Infrared spectra in the region $4000-200 \mathrm{~cm}^{-1}$ were recorded in $\mathrm{KBr}$ on Perkin Elmer Model 1620 FT-IR spectrophotometer by Jamia Millia Islamia University, New Delhi, India. Conductometric measurements were done on Systronics 321 Conductivity Bridge. The metal dithiocarbamate complexes may be synthesized either by insertion reaction method or by replacement reaction method. In the present work the second was adopted for the synthesis.

Dimethylamine, sodium hydroxide and carbon disulphide were taken in 1:1:1 molar ratios respectively. Sodium hydroxide $(0.1 \mathrm{~mol})$ was dissolved in $50 \mathrm{~mL}$ distilled water and into it $0.1 \mathrm{~mol}$ of dimethylamine was added carefully with constant stirring by means of a magnetic stirrer. $0.1 \mathrm{Mol}$ of carbon disulphide was then added drop by drop keeping the temperature $12-16{ }^{\circ} \mathrm{C}$. The stirring was continued at room temperature for about 45 minutes. On completion of the reaction solid sodium dimethyldithiocarbamate was obtained. The separated solid salt was filtered off and washed with toluene. It was dried at $80{ }^{\circ} \mathrm{C}$. This salt was soluble in water.

In appropriate molar ratio (1:2) the $0.01 \mathrm{M}$ solutions of metal salts of the type $\mathrm{MCl}_{2}$ were added to $0.02 \mathrm{M}$ aqueous solution of sodium dimethyldithiocarbamate dissolved in distilled water at $20{ }^{\circ} \mathrm{C}$. In 1:3 molar ratio $0.01 \mathrm{M}$ solutions of the metal salts of the type $\mathrm{M}^{\prime} \mathrm{Cl}_{3}$ were added to the $0.03 \mathrm{M}$ solutions of sodium dimethyldithiocarbamate. The stirring was continued for 3 hours at $20{ }^{\circ} \mathrm{C}$ and then the reaction mixture was cooled to $0{ }^{\circ} \mathrm{C}$. The precipitated solid substance was filtered, washed with ice water and dried in the air.

\section{Results and Discussion}

The replacement reaction method yielded compounds of high purity, which was supported by analytical data (Table 1). The colourless to colourful compounds were air and moisture stable at room temperature. These complexes were soluble in water, ethanol, benzene and DMF. The low molar conductance values of $10^{-3} \mathrm{M}$ solutions of these complexes in DMF at room temperature lying in the range 6.03 to $10.87 \mathrm{ohm}^{-1} \mathrm{~cm}^{2} \mathrm{~mol}^{-1}$ confirmed the nonelectrolytic behaviour ${ }^{22}$ of all the complexes.

Table 1. Analytical data and other physical properties of dimethyldithiocarbamate

\begin{tabular}{|c|c|c|c|c|c|c|c|c|c|}
\hline \multirow{2}{*}{$\begin{array}{l}\text { Compounds } \\
\text { (Formula Wt.) }\end{array}$} & \multirow{2}{*}{$\begin{array}{c}\text { Yield, } \\
\%\end{array}$} & \multirow{2}{*}{$\underset{{ }^{\circ} \mathrm{C}}{\mathrm{M} . \mathrm{P} .}$} & \multirow{2}{*}{ Colour } & \multirow{2}{*}{$\begin{array}{c}\Lambda_{\mathrm{m}} \\
\mathrm{ohm}^{-1} \mathrm{~cm}^{2} \mathrm{~mol}\end{array}$} & \multicolumn{5}{|c|}{ Found (calculated) $\%$} \\
\hline & & & & & C & $\mathrm{H}$ & $\mathrm{N}$ & $S$ & $\mathrm{M}$ \\
\hline $\begin{array}{l}\text { 1. } \mathrm{Na}\left(\mathrm{Me}_{2} \mathrm{dtc}\right) \\
(143)\end{array}$ & 68 & 165 & Orange & ---- & $\begin{array}{l}25.11 \\
(25.17)\end{array}$ & $\begin{array}{c}4.17 \\
(4.20)\end{array}$ & $\begin{array}{c}9.83 \\
(9.79)\end{array}$ & $\begin{array}{c}44.85 \\
(44.76)\end{array}$ & ------ \\
\hline $\begin{array}{l}\text { 2. } \mathrm{Cr}\left(\mathrm{Me}_{2} \mathrm{dtc}\right)_{3} \\
(411.99)\end{array}$ & 70 & 156 & Green & 8.75 & $\begin{array}{c}26.42 \\
(26.26)\end{array}$ & $\begin{array}{c}4.33 \\
(4.36)\end{array}$ & $\begin{array}{c}10.15 \\
(10.19)\end{array}$ & $\begin{array}{c}46.45 \\
(46.58)\end{array}$ & $\begin{array}{l}12.65 \\
(12.61)\end{array}$ \\
\hline $\begin{array}{l}\text { 3. } \mathrm{Mn}\left(\mathrm{Me}_{2} \mathrm{dtc}\right)_{2} \\
(294.94)\end{array}$ & 71 & 173 & $\begin{array}{l}\text { Light } \\
\text { yellow }\end{array}$ & 10.87 & $\begin{array}{c}24.32 \\
(24.41)\end{array}$ & $\begin{array}{c}4.08 \\
(4.06)\end{array}$ & $\begin{array}{l}9.55 \\
(9.49)\end{array}$ & $\begin{array}{c}43.29 \\
(43.41)\end{array}$ & $\begin{array}{c}18.76 \\
(18.63)\end{array}$ \\
\hline $\begin{array}{l}\text { 4. } \mathrm{Fe}\left(\mathrm{Me}_{2} \mathrm{dtc}\right)_{3} \\
\quad(415.85)\end{array}$ & 69 & 180 & $\begin{array}{l}\text { Dark } \\
\text { brown }\end{array}$ & 9.87 & $\begin{array}{l}25.88 \\
(25.97)\end{array}$ & $\begin{array}{c}4.37 \\
(4.33)\end{array}$ & $\begin{array}{c}10.17 \\
(10.10)\end{array}$ & $\begin{array}{c}46.08 \\
(46.17)\end{array}$ & $\begin{array}{l}13.50 \\
(13.43)\end{array}$ \\
\hline $\begin{array}{l}\text { 5. } \mathrm{Co}\left(\mathrm{Me}_{2} \mathrm{dtc}\right)_{2} \\
(298.93)\end{array}$ & 73 & 181 & $\begin{array}{l}\text { Light } \\
\text { green }\end{array}$ & 7.30 & $\begin{array}{l}24.28 \\
(24.09)\end{array}$ & $\begin{array}{c}4.03 \\
(4.01)\end{array}$ & $\begin{array}{c}9.33 \\
(9.37)\end{array}$ & $\begin{array}{c}42.71 \\
(42.82)\end{array}$ & $\begin{array}{c}19.65 \\
(19.71)\end{array}$ \\
\hline $\begin{array}{l}\text { 6. } \mathrm{Ni}\left(\mathrm{Me}_{2} \mathrm{dtc}\right)_{2} \\
(298.71)\end{array}$ & 67 & 342 & Green & 7.83 & $\begin{array}{l}24.01 \\
(24.11)\end{array}$ & $\begin{array}{c}3.99 \\
(4.01)\end{array}$ & $\begin{array}{c}9.40 \\
(9.37)\end{array}$ & $\begin{array}{c}42.78 \\
(42.86)\end{array}$ & $\begin{array}{l}19.82 \\
(19.65)\end{array}$ \\
\hline $\begin{array}{l}\text { 7. } \mathrm{Cu}\left(\mathrm{Me}_{2} \mathrm{dtc}\right)_{2} \\
(303.55)\end{array}$ & 65 & 169 & Brown & 10.23 & $\begin{array}{l}23.61 \\
(23.72)\end{array}$ & $\begin{array}{c}3.97 \\
(3.95)\end{array}$ & $\begin{array}{l}9.18 \\
(9.22)\end{array}$ & $\begin{array}{c}42.39 \\
(42.17)\end{array}$ & $\begin{array}{l}20.85 \\
(20.94)\end{array}$ \\
\hline $\begin{array}{l}\text { 8. } \mathrm{Zn}\left(\mathrm{Me}_{2} \mathrm{dtc}\right)_{2} \\
(305.37)\end{array}$ & 72 & 160 & Colourless & 6.03 & $\begin{array}{c}23.49 \\
(23.58) \\
\end{array}$ & $\begin{array}{c}3.91 \\
(3.93)\end{array}$ & $\begin{array}{c}9.21 \\
(9.17) \\
\end{array}$ & $\begin{array}{l}42.04 \\
41.91) \\
\end{array}$ & $\begin{array}{l}21.35 \\
(21.41)\end{array}$ \\
\hline
\end{tabular}


The monodentate or bidentate nature of dithiocarbamato group in the ligand is reflected ${ }^{23}$ in the $v(\mathrm{C}-\mathrm{S})$ stretching frequency. In the case of bidentate behaviour, a single strong band appears in the region $950-1050 \mathrm{~cm}^{-1}$, while a doublet is expected in the region around $1000 \mathrm{~cm}^{-1}$ for the monodentate one.

The IR spectra of solid complexes showed well-resolved and sharp bands (Table 2). The bands observed in the wave number range $1485-1496 \mathrm{~cm}^{-1}, 1002-1010 \mathrm{~cm}^{-1}$ and $473-480 \mathrm{~cm}^{-1}$ were clearly attributable to $v(\mathrm{C}-\mathrm{N}), v(\mathrm{C}-\mathrm{S})$ and $v(\mathrm{M}-\mathrm{S})$ respectively.

In view of all these experimental facts, we could conclude that this dithiocarbamate ligand showing bidentate nature, formed four membered chelate rings in complexation with metals. The metal(M) was observed to be tetracoordinated in $\mathrm{ML}_{2}$ type chelates and in $\mathrm{M}^{\prime} \mathrm{L}_{3}$ type, it was hexacoordinated.

Table 2. IR spectral data of dimethyldithiocarbamate complexes

\begin{tabular}{cccc}
\hline Complexes & $v(\mathrm{C}-\mathrm{N}) \mathrm{cm}^{-1}$ & $v(\mathrm{C}-\mathrm{S}) \mathrm{cm}^{-1}$ & $v(\mathrm{M}-\mathrm{S}) \mathrm{cm}^{-1}$ \\
\hline $1 . \mathrm{Na}\left(\mathrm{Me}_{2} \mathrm{dtc}\right)$ & 1490 & 989 & --- \\
2. $\mathrm{Cr}\left(\mathrm{Me}_{2} \mathrm{dtc}\right)_{3}$ & 1495 & 970 & 380 \\
3. $\mathrm{Mn}\left(\mathrm{Me}_{2} \mathrm{dtc}\right)_{2}$ & 1494 & 972 & 350 \\
4. $\mathrm{Fe}\left(\mathrm{Me}_{2} \mathrm{dtc}\right)_{3}$ & 1502 & 970 & 366 \\
5. $\mathrm{Co}\left(\mathrm{Me}_{2} \mathrm{dtc}\right)_{2}$ & 1510 & 975 & 371 \\
$6 . \mathrm{Ni}\left(\mathrm{Me}_{2} \mathrm{dtc}\right)_{2}$ & 1532 & 974 & 384 \\
7. $\mathrm{Cu}\left(\mathrm{Me}_{2} \mathrm{dtc}\right)_{2}$ & 1528 & 976 & 352 \\
$8 . \mathrm{Zn}\left(\mathrm{Me}_{2} \mathrm{dtc}\right)_{2}$ & 1525 & 975 & 379 \\
\hline
\end{tabular}

\section{Acknowledgement}

I am highly grateful to the Chairman and the Director, B.I.T.S. Ghaziabad (UP), India for providing the necessary infrastructure for this work.

\section{References}

1. Baird M C and Wilkinson G J, J Chem Soc A, 1967, 865.

2. Cotton F A and Walton R A, Multiple Bonds Between Metal Atoms, Ed. II (Oxford) 1993, 682.

3. Srivastava S, Srivastava V, Chaturvedi K, Pandey O P and Sengupta S K, Thermo Chim Acta, 1994, 240, 101.

4. Hey-Hawkins E, Chem Rev., 1994, 94, 1661.

5. Cloke F G N, Comp Organo Met Chem II, (Perg. Press Oxford) Vol. IV, 1995.

6. Manohar A, Venkatachalam V, Ramalingam K, Casellato U and Graziani R, Polyhedron, 1997, 16, 1971.

7. Das D and Sinha C, Indian J Chem., 1998, 37A, 531.

8. Bhatt A, Sengupta S K and Pandey O P; Indian J Chem., 2001, 40A, 994.

9. Tarique M and Aslam M, Oriental J Chem., 2008, 24(1), 267.

10. Tarique M and Aslam M, Biosci Biotec Res Asia, 2008, 5(1), 355.

11. Tarique M and Aslam M, Biosci Biotec Res Asia, 2008, 5(2), 833.

12. Tarique M and Aslam M; Acta Ciencia Indica, 2008, XXXIV C(4), 635.

13. Tarique M and Aslam M, Oriental J Chem., 2009, 25(1), 207.

14. Tarique M and Aslam M, Acta Ciencia Indica, 2009, XXXV C(1), 77.

15. Tarique M and Aslam M, Asian J Expl Chem., 2009, 4(1-2), 46-48. 
16. Tarique M and Aslam M, Asian J Expl Chem., 2009, 4(1-2), 87-89.

17. Tarique M and Aslam M, Asian J Chem., 2010, 22(3), 2031-2034.

18. Tarique M and Aslam M, Asian J Chem., 2010, 22(3), 2465.

19. Tarique M and Aslam M, E-J Chem., 2011, 8(4), 2020.

20. A. I. Vogel, A Text Book of Practical Organic Chemistry, (ELBS and Longmans, London), 1968.

21. A. I. Vogel, A Text Book of Quantitative Inorganic Analysis, Ed III (ELBS and Longmans, London), 1960, 453, 427, 312.

22. Geary W J, Coord Chem Rev., 1971, 7, 81-122.

23. Druce P M, Kingston B M, Lappert M F, Spalding T R and Srivastava R C, J Chem Soc., A, 1969, 2106. 